\title{
Winter Carnival in Vevchani (Republic of North Macedonia) as the Model of Traditional Holiday and Modern Cultural Practice
}

\author{
Oksana Mykytenko
}

The paper is based on field research observations in Republic of North Macedonia, where in 2019 I witnessed the folklore carnival "Vasilitsa", annually held on the $13-14^{\text {th }}$ of January in the village of Vevchani near Ohrid. Tradition of the winter masking carnival exists on the whole ethnic territory of Macedonia with different names of its participants. The traditional drama play (P. Bogatyrev, M. Kitevski) imitates the wedding ritual and is called to actualize the semantics of fertility. Today we observe the simultaneous coexistence both traditional and modern elements that promote carnival in Vevchani, maintaining its status as the sign of the local and national identity. Analyzing in the context of globalization process with its dominants of multicultural trends and idea of consumption, the carnival in Vevchani depicts the synergy of the traditional and modern holiday culture.

Keywords: Republic of North Macedonia, Vevchani, carnival "Vasilitsa”, folklore tradition, modern culture

The ritual as a sign system that creates a "model of group identity" plays decisive role and significance in the system of traditional culture (Гаврилюк 1999: 7), it becomes a marker of some local tradition, determines the affiliation of the individuals and rural communities to it. "Ritual identity" arises during the ritual action, sensually unites the participants of the rite, creates its emotional background and reveals the sacred values of the group of people. Thus, the traditional holiday custom, which in this context can be described as a process that directs emotions, feelings, thus creating "we are the image of community" (Скиба 2004: 33), acquires special significance in terms of identity formation as a phenomenon of sociocultural life as at the micro and macro levels, both ethnic and national. 


\section{Traditional holiday "Vasilitsa" on the example of Vevchani village}

The calendar cycle of traditional rituals, marked by high semiotic weight and mythological significance, includes, in particular, holidays and rites of the New Year and Christmas period, which continue their active life today. Folklore festivals in the North Macedonia are represented by a "multi-layered folk culture", which combines Christian rites and pre-Christian customs and beliefs. Such holidays were of great importance for people in the past, and are preserved today (Китевски 2001: 5, 28). In 2019, I witnessed such a folk festival "Vasilitsa" - a bright carnival event, which takes place annually in the Vevchani village (around $25 \mathrm{~km}$ north-west from Ohrid). The Vevchani Carnival has never faded or been interrupted, and since 1993 it has been a member of the International Carnival Federation ${ }^{1}$. Following its example and initiative to revive the tradition, a national association of carnivals was established, which included the cities of Strumica, Prilep and others. Here, as in other New Year's holidays in Macedonia, traditional forms of celebration can be traced, as well as new models, forms and elements of custom. It is obligatory to go around the village in two groups from two corners of the village, the characters of the ritual action - son-inlaw, daughter-in-law, fool; dressing up, greeting the villagers named Vasyl, visiting water sources, celebrating in the center of the village, general merriment (Китевський 2009: 91).

The name of the ritual holiday is associated with St. Basil's Day (January $14^{\text {th }} /$ January $1^{\text {st }}$ ), which symbolically opens a new year (according to the Julian calendar), and takes place in the period from Christmas to Epiphany, during 12 so-called "unbaptized" and the most dangerous days associated with many ritual prohibitions and recommendations (Поповски 1975: 251). These 12 days, filled with many beliefs from the Pre-Christian period, are considered by the Macedonians, as indeed by many other nations, as especially dangerous. At that time, according to folk belief, many demonic creatures are active (fairies, 'karakondzuls', vampires, 'tolosums'), which can harm people, cattle and property in general. The whole period is accompanied by various interdictions with a protective aim (Mirchevska

\footnotetext{
${ }^{1}$ Founded in the 1980 s, originally as an association between cities Patras (Greece) and Amsterdam (Netherlands), with its center in Amsterdam. Among the first member countries - Belgium, Holland, Greece, Luxembourg, Great Britain, Malta. In 2003, a convention was signed between the members of the association in Portugal, and in 2004, at a meeting of member countries in Pernik, Bulgaria, during the Biennial Game of Masks, the association changed its name to the Federation of European Carnival Cities (FECC). Among the main tasks of the federation is the exchange of experience and ideas regarding the carnival, as well as the preservation of intangible cultural heritage (Марјановић 2011: 11).
} 
2008: 162). New Year's rites and songs belong to those where "pagan features" have been preserved, while the Christian elements introduced by the church are insignificant or non-existent (Китевски 2002: 123). Ritual merriment, important as a talisman and a means of protection from otherworldly forces played a special role among the ritual actions in this period (Толстой 1995: 306). The most common was a folk game in which only men participated and which contained "all the elements of dramatic action" - characters, masks, monologues, dialogues, stage, scenography, audience, and so on. The ritual game was "taken very seriously", and the rite itself was "extremely important" (Китевски 2001: 49; Китевський 2009: 89). According to popular belief, the purpose of such a rite was to "expel everything that remained bad from the old year", in particular, to expel Karakondzula, a mythological creature who embodied evil, and thus show that the participants themselves have power and authority (Младеновски 1975: 380). The semantics of ritual exile was also confirmed at the level of ritual actions and attributes, which had a symbolic meaning. So, in the villages around Kumanovo, when a group of dressed men left the house, the owner threw badnik (oak logs, which were burned on Holy Evening) after them. The children, playing pushed in the back such dressed-up "priest" so that he would "take the bad out of the house". Badnik was also used to make a cross, which was shod with straw and left in the field "for the harvest" (Здравев 1975: 372).

Among the characters of the Vasilitsa ritual games, which began at midnight and lasted until sunrise, were the head masks - old man and old woman, son-in-law and daughter-in-law, elders, etc., as well as secondary "army" (priest, guards, gendarmes, "blackamoor", cameleer, etc.). Reincarnations played an important role - masking and dressing, according to the role played by one or another participant. Today, carnival clothes as well as various masks are usually bought. Faces used to be often smeared with soot or brightly-painted, today ready-made cosmetics are used for multi-colored make-up. Masks used to be made of paper, animal skins, there were masks with animal horns and so on. Mustaches or beards were made of hemp or wool. Bells and beaters were attached to the belt, which had a ritual function. The obligatory attribute of the participants was the fruitful dogwood (or other) branches and twigs with which they whipped the girls and other family members, including pets, which had a ritual significance and corresponded to the general semantic orientation of the ritual game. 


\section{Morphology of the ritual text: geography, terminology, participants, verbal communication}

Understanding of folklore and folk culture "as a comprehensive whole" presupposes, first of all, the semantic interpretation of the syncretic in its nature folklore phenomenon, and the text as a key category of culture. At the same time, while considering ritual folklore, the semiotic understanding of the rite as a text is emphasized (Толстой 1995: 48). The "grammar" of the text is represented by a sequence of symbols united by ritual syntax, while the "action" code, expressed by ritual actions, forms its predicative system. In the text of the rite, predicates become part of symbolic communication, and the action acquires the meaning of ritual behavior, which corresponds to the system of codes of traditional culture. Radenkovich considers the participants, time and place of the event, as well as ritual objects and verbal texts to be elements of ritual behavior that have a symbolic character. Thanks to such elements, not only the ritual action takes place, but also the movement of tradition is ensured (Раденковић 2019: 96).

In different parts of Macedonia, the masked men have different names. Participants of the Vasilitsa rite, known throughout the ethnic territory of Macedonia, were called differently in different regions: near Ohrid, Struga and Veles they were called vasilichari, in Prilep and Bitola region babari, in Skopje and Tikvesh dzamalari/dzalamari, near Razlog survakari, around Kostur, other parts of Aegean Macedonia eshkari, as well as known among the Southern Slavs surati, mechkari/machkari, kamilari, bushari, buchani, zvonchari, kugachi, nap hantsi, etc. (Китевски 2001: 50; Плотникова 2004: 105; Mirchevska 2008: 162; Константинов 1975: 375). Significant differences are observed in each local tradition of Macedonia both in terms of the figurative system of ritual and in general the "ritual and entertainment concept of the game". Ritual games had their own characteristics in different places; in particular, in Smilevo the game took place as a pantomime, without verbal text, in other villages - near Krushevo, Bitola, Prilep, the participants sang and conducted dialogues (Здравев 1975: 369; Константинов 1975: 377).

Petrovska-Kuzmanova notes: "In our region, we meet vasilichari masked groups under different names (vasilichari, sirovari, babars, jamalars, etc.), but for all of them it is characteristic that participants only men who represent the wedding procession, which includes: 1) 'fortune teller', 'father-in-law'; 2) 'feller', 'blackamoor', 'son-in-law'; 3) 'daughter-in-law'; 4) 'priest'; 5) 'bear', 'bear leader', as well as 6) 'master', who meets the group at home and has a significant role in the ceremony" (Петровска-Кузманова 2006: 70). The name of the rite corresponded, as a rule, to the main char- 
acters - masked members of the ritual team, who were often similar in different local traditions, which is a common feature of traditional customs in the Balkans (Мишкова 2017: 300). At the same time, the area of Macedonia and adjacent southern Serbia and western Bulgaria are defined as a corresponding homogeneous complex of festive rituals and masking in the South Slavic region (Толстой 1995: 115).

According to Nikita Tolstoy, "there are dialectal features in the festive performances of Macedonian and Western Bulgarian maskers", in particular, there is an "interesting picture of the dialectal diversity of the rite" (Толстой 1995: 115, 118). If terms such as survakari (derives from the Slavic surov- 'strong, healthy, raw') are inherent to winter ritual rounds in most of the South Slavic dialect area, then New Year's games dressed with "obscene" motifs or imitation of a wedding are recorded in Macedonia and the region of western Bulgaria and Southeastern Serbia. In South-Western Bulgaria, on St. Basil's Day, these were dzamali, starci, represented by unmarried youth, greeting the hosts with long and solemn blessings (Анастасова 2004: 25). The extraordinary variety of characters and names of games (arapi, babugeri, dervishi, dzamali, kalugeri, kamila, starci) is demonstrated, while maintaining the basic masks of "bride" and "groom", New Year and Christmas masquerade customs in areas with Slavic-speaking population in the territory of Northern Greece (Мишкова 2017: 301).

The most general semantics of the tradition of ritual processions is the meaning of "symbolic coverage", "belonging" and "accession" (Раденковић 2019: 111). According to surveys, there are two types of New Year's processions in Macedonia: along with the carnival procession (games of costumed), there is a traditional ceremonial procession of the group survakari and so on. Despite the fact that in Macedonia there is a limited use of terminological vocabulary-derivatives from *surva-, even often the name of the ritual procession is not exist, the word сурва (surva) is used in the formulas of traditional greetings (Macedonian: Сурва, сурва година, весела, весела година!) (Плотникова 2004: 104-105), as well as in folklore texts Сурова, сурова година (Китевски 2001: 50).

Formulas from surva were part of the traditional wishes during the ritual raking of ashes in the hearth, typical of the Christmas and New Year cycle. It was believed that this was done to "give birth to a boy", (Macedonian: да се роди машко дете). Jamalari, Vasilichari and other carols singers uttered greetings (Macedonian: Колку искри, толку керки...). In the villages of Ohrid, the New Year's processions of the vasilichari include a ritual whipping with a plum twig with the wish Суров(a) да си! In the village Peshtany family ritual with New Year's bread is accompanied by a three-time exclamation Суров(a) да сu! In the village Maleshevo (Eastern Macedonia) guys with sticks who walked around the village on New Year's Eve, whipping the 
elderly with the words: Сурова дедо! (Сурова баба!), and parents woke up children (boys) at midnight, who ran through the streets, shouting loudly: Сурва! and announcing the coming of the New Year (Плотникова 2004: 106).

Traditionally, children participated in New Year and Christmas customs separately from the adult population, and their actions, as well as verbal texts, were similar throughout the New Year and Christmas cycle. Today, children are active participants in vasilichari carnival activities. Groups of children in masks, dressed in bright carnival costumes, go from house to house, visiting relatives and acquaintances. Meanwhile, if earlier, as one of the participants of the patrols recalls, "the children went in groups of three or four, one of whom was a 'son-in-law', one a 'daughter-in-law' and two more accompanied, today everyone goes separately" (ПетровскаКузманова 2006: 77). At the same time, ritual songs performed by children and adults differ even today. If the adult members of the vasilichari groups sing songs of "vulgar content": Оро оро ориште, Отвори Мато вратата, Бара, бара барила, etc., the songs performed by children on the New Year under the Julian calendar (Vasilitsa) were similar to carols, or identical to those songs performed on Christmas Eve (Китевски 2002: 128). Blazhe Rystovsky was one of the first who analyzed and drew attention to the need to collect and research ceremonial male erotic folk songs performed on Holy Evening and on St. Basil's Day near the common fire and have a distinctly "orgiastic character" its spiritual culture, emphasizing their importance for understanding "human life and its spiritual culture" (Ристовски 1975: 219).

On Vasilitsa (as well as on Christmas) groups of school-age children first gathered around a common fire, and then walked around the village, going into the house and saying (chanting) similar to carols (and the same motives) greeting texts in which they expressed wishes for the New year, for which they received from the owners treats - sweets, nuts, apples, etc. (Китевски 2001: 53; Китевски 2002: 128-129; Николовски 1992: 195). The children, holding surva plum, thorn branches or other fertile trees, hit the audience with them (what was called суројат, суруваат), especially the old and infirm, as well as livestock, so that they were healthy all next year, with the words: Суро, суро, до години повесели, порадосни (Suro, suro, in a year even more cheerful, even happier) (village Slatino), or Сурова, сурова година (village Leshany) (Китевски 2001: 50-51; Малинов 2006: 217; Николовски 1992: 195). Branch blows - "one of the universal manifestations of human ritual behavior", had the role of "symbolic communication" (Раденковић 2019: 107), and the rite was called surovenje, at all levels of which there is an actualization of the semantics of surov- (in verbal communication, in actions participants and paraphernalia). 
In different districts and villages, the actors of the groups and the actions they performed differed. In the area of Ohrid and Struga, where rituals traditionally took place on the eve of St. Basil's Day, members of men's groups (often up to 30-50 people) were mostly unmarried young people, as well as several older men recognized in the village of merrymakers who knew how to joke and knew custom. Two groups of vasilichari are formed: gornomaalski and dolnomaalski (from the lower and higher settlements of the village). The leaders of the groups are the 'bridegroom' and the 'bride'. They wear folk costumes and go round the village visiting all houses. The presence of the bride-groom and the bride has also been noted among other ethnic groups (Mirchevska 2008: 162). As a rule, the band gathered on the eve of the holiday in the center of the village (Macedonian срецело), participants lit a fire and from here at midnight, with songs and music (previously musical instruments were gajda (bagpipes), kaval (large flute), shupelka (flute), in recent times, usually clarinet, harmonica, drum), went around the village. They had to return by morning and to the same place where they came from (Николовски 1992: 194).

Ritual games with masks are exclusively part of male rituality (Mirchevska 2008: 162). Women usually visited relatives and neighbors, and brought with them small firewood, which they threw into the hearth, ordering: “Да се родат дечиња, пилиња, јагниња, телиња, јариња, ждребиња..." ("Let children be born, chickens, lambs, calves, goats, foals...") (Николовски 1992: 195).

\section{Ritual game: masks and texts}

Ritual masking of vasilichar male groups in Macedonia, as in other regions of the Balkans, belongs to the group type of ritual travesty, which is a manifestation of a special form of so-called anti-behavior during the New Year and Christmas period. "The mask in the eyes of the observer - emphasizes Radenkovich - changes one reality to another, everyday and real to fantastic, thanks to its ordinary people turn into mythological images" (Раденковић 2019: 127). At the same time, "the process of masking today is clearly a mixture of traditional and contemporary forms of expression. The magical aspect is largely absent" (Mirchevska 2008: 164).

Mikhail Bakhtin, characterizing the role of the mask in world culture, in particular, in the folk holiday, emphasizes its importance as one of the "most complex and ambiguous motives" of traditional culture. "The mask", he notes, "is associated with the joy of change and reincarnation, with a cheerful relativity, with a cheerful denial of identity and unambiguity". It is associated with "transitions, metamorphoses, violations of natural bound- 
aries, with ridicule". It embodies the "playful beginning of life, it is based on a completely different relationship between reality and image, characteristic of the most ancient ritual and entertainment forms". This meaning of the mask is revealed precisely when it "functions in the organic integrity of folk culture", where the mask is always "inexhaustibility and diversity of life" (Бахтин 1990: 48).

The term 'mask', derived from Latin, is not typical of the Macedonian language and was not used until the early twentieth century. From the basis of the same noun in the South Slavic tradition was known the term Macedonian: маскара, машкара 'mask', 'man in a mask', 'dressed up', borrowing from the Judeo-Spanish dialect, which had an "unpleasant and offensive meaning" (Константинов 1975: 376). Instead, the name cypam/u, which comes from Arabic through Turkish language mediation, has been widely used and still is used. In particular, the carnivals that took place in Ohrid for a long time were called Surat, when residents not only bought readymade masks, but also made them themselves (from fabric, cardboard, pet skins, using animal bones, wood, dry grass, metal, etc.). The most popular masks were "Arab in a turban with a tassel", "son-in-law and daughter-inlaw", "grandfather and grandmother", "male gypsy and female gypsy" and others (Маленко 1975: 385).

\section{Ambivalence of anti-behavior as a manifestation of ritual pragmatics}

"What makes a carnival a 'carnival' in the most general sense?", Vesna Maryanovich asks and gives the answer: "First of all, the carnival differs in the context of allowed and forbidden behavior" (Марјановић 2011: 12). Carnival inversion is not chaos against reality, it means the rotation of reality, the creation of an imaginary, different world, a certain ritualization of order and chaos (Lozica 1997: 242). Forms of anti-behavior as a manifestation of ritual action express the general direction of the rite, represented by a system of binary oppositions, which is the ambivalence of the traditional text. In addition to masking, the manifestations that emphasized the mythological significance of the ritual included other "carnival-brutal communication" "elements of ancient laughter cultures", which, according to Bakhtin, "reducing and killing, in the same time reviving and renewing" (Бахтин 1990: 23).

Anti-behavior is present at all levels of the ritual game "Death and Resurrection of the Elder" (Спировска 1975: 365), which usually began in the yard. The saying to the imaginary "dead" was a combination of rhyming nonsense phrases, vulgar vocabulary, listing the parts of the body of 
the "dead", which can be useful in the household and which should be given to those present: "head - children to play football", "hands will agree on a comb for wool", "spindle" - to daughters-in-law on spins, etc. The improvised series could be quite wide, which depended on the wit of the "healer" and the number of spectators, each of whom must be "endowed" with his share, which in an atmosphere of general fun and jokes is supported by applause.

When the vasilichars were not allowed to enter the house to avoid "obscenities", they performed a ritual performance in the yard, for which they also received gifts. However, if there were no gifts, they tried to harm the owner, in particular breaking what was in the yard - a plow, harrow, cart, etc. The host also had to make sure that what could be used by the participants for the common fire was not stolen from his yard at night. Such actions were of a ceremonial nature, they were not ashamed or condemned (Китевски 2001: 52; Ристовски 1975: 223). The peasants also paid attention to avoid the meeting of two vasilichar groups, which inevitably led to a fight, and often the death of one of the participants (Малинов 2006: 214). It is clear that the purpose of the ritual "conflict" with skirmishes and fights, which was, according to Petrovska-Kuzmanova, to "ensure the wealth and well-being of the community", today disappears or changes, as well as changes the symbolic meaning of ritual dressing. Two "parties", which also gather from two corners of the village (usually its upper and lower parts), meet at the end of the ceremony in the center of the village, where they lead a ceremonial kolo (circle), giving an explanation "not to divide the audience" (Петровска-Кузманова 2006: 69), which indicates the transformation of ritual action into a modern spectacle. The symbolic function and conventionality of the costumes of the participants as representatives of the "chthonic world" today is also gaining a more noticeable comic sound, for which the "inversion" of sham and props as elements of the carnival costume is often emphasized.

The factor that determined the ritual anti-behavior for a certain period was the presence of a core concept, in particular vasilichar fire. The children's songs, with which they addressed the adults during the ceremonial awakening, urging them to gather brushwood for the fire on St. Basil, contained "vulgar expressions". Ritual erotic texts (short, with obligatory rhyme and the use of profanity), sung in a recitative, chanting, the men around the common fire, had the character of "expressive glorification of the genitals and sexual intercourse". Such a "carnival atmosphere" in many regions of Macedonia was alive in the 70's of the twentieth century, and according to the oldest informants, free-singing songs were performed, both "in the Turks time" and in the days of the SFRY, when the "gendarmes" themselves joined ceremonial fire (Ристовски 1975: 220-225). 
The anti-behavior associated with the pragmatics of the rite embodied the semantics of surov- as a main imperative of the rite, emphasizing that "the main meaning is to call for fertility" (Толстой 1995: 118). Other manifestations of ritual anti-behavior had the same functional orientation, which can be seen more clearly in comparison with other variants of Christmas and New Year rites, when the male community represented the "army" (Анастасова 2004: 25).

Thus, anti-behavior as a replacement of normative forms of behavior on the contrary was a manifestation of magical practice and had the direction of both protective magic and "model the desired state" (Левкиевская 2004: 680). Together with other traditional ritual actions, the rite was to ensure fertility, symbolically influence time and confirm the boundaries of "own" space within the calendar cycle.

The idea of fertility can also be traced in the interpretation of the rite as a visualization of a myth in which masked male groups of unmarried youth appear as a metaphor for the text of initiation, told in the language of parody (Бояджиева-Пеева 2013: 227). In addition, taking into account not only the Slavic parallels (in particular, ritual games with the deceased), but also the Balkan traditions of the New Year's processions, researchers emphasize the connection of the rite with ancient cults during the celebrations of the winter solstice and spring equinox. The rite launched a new time cycle, giving it the appropriate social, cultural and spiritual significance. For human beings, participation in magical actions was a confirmation of his or her involvement in the creation of a new time cycle, which thus received a human dimension (Малинов 2006: 217).

\section{Divination as a form of symbolic communication}

According to Bakhtin, "all kinds of divination, fortune-telling and wishes" are "inseparably connected" with the atmosphere of the people's holiday (Бахтин 1990: 255). On Vasilitsa (St. Basil day) divination for wellbeing, health and a happy New Year traditionally took place. Such actions, which symbolically predicted time, in the folk-festive atmosphere of the New Year and Christmas cycle were organically associated with the ritual game and remain one of the most stable elements in the context of modern custom. We had the opportunity to see that today in the village Vevchani on Vasylitsa, in a homemade fresh puff pastry (Macedonian: numa, погача, баница, губа), which is baked for a festive dinner, they put a small coin. It is believed that whoever finds it will be happy and rich all year round (ќe биде срекен, касметлија во текот на целата година). In South-Western Bulgaria for the New Year or Vasilovden they arrange a special kadena vecherya, 
which obligatory include pogacha, banica and pita with "happiness" (Bulgarian $к ъ с м е т)$ ), as well as roast suckling pig (Анастасова 2006: 25). Scientists say that the custom of divination on the New Year, when a small coin was inserted into the baked dough (Macedonian топљеница, топеница, топејнца, pieces of bread soaked in hot lard), and those who found it would be lucky in the new year, contain records from Struga and Ohrid by researchers of the $19^{\text {th }}$ - early $20^{\text {th }}$ centuries Sprostranov and Shapkarev. Such a coin, which was believed to be able to "attract" money, was kept in a wallet or tied with a red thread around the neck of the first-born lamb (quoted by: Малинов 2006: 218).

Traditionally, in the region of Ohrid and Struga, divination was performed in such a way that wheat grains were placed in hot ashes or hot shards, watching how many times the grain "jumped", which was a good sign and meant prosperity. They guessed both family members and cattle or crops. In addition, frying pans were placed between the two shards, observing whether they would leave white ashes, which was a good sign, or go out, becoming black cinders, which foretold disease or other misfortune. It was also believed that everyone should wear something new on Vasilitsa and wear it throughout the year (Китевски 2001: 52-53; Малинов 2006: 218). As a ritual aimed at establishing contact with otherworldly forces in order to gain knowledge about the future (Виноградова 1995: 482), divination, structurally actualizing the first member of the opposition up - down, white - black, new - old, etc., reveals a common traditional worldview antinomy and has a broad Slavic character.

\section{From ceremonial syncretism to a carnival spectacle: the experience of Petr Grigor'evič Bogatyrev}

The antinomy of the old and the new, when, according to Bakhtin, "the debunking of the old and the crowning of the new" takes place in the base of the ideological concept of the calendar ritual action. The combination of various forms of folk spectacle with the concept of time, which becomes a "true hero of the holiday", determines the carnival nature of the action, where time acquires the characteristics of "fun" (Бахтин 1990: 243).

Given the ambivalent meaning of carnival as "death fraught with life", carnival is defined not only as a set of features that recreate the atmosphere of the carnival, but also as a reflection of a special worldview inherent in folk entertainment culture, based on the idea of unity of opposites: life - death, top - bottom, praise - cursing, crying - laughter, etc.), perceived through the prism of contemplative universal laughter. Characteristic features of carnival are: system of travesties (sorting, mystification) 
and inversions (hierarchical or role permutations; counteraction to official behavior and way of life), violation of proportions, lack of pure denial, ambivalent laughter due to merry beating, debunking, reduction of images, alogism etc. (Некрылова 1993: 110). Bakhtin noted that the concept of carnival for the Slavic traditions is rather conditional, because in contrast to Western Europe, the process of combining "diverse local phenomena is not over", and "various forms of folk festivities as a general, and local character (Shrovetide, holiday, fair, etc.) remained ununited". Because of this reason we can speak with confidence about the "carnival atmosphere" of folk festivals, as well as about the "genetic sources of holiday images and images of the game" (Бахтин 1990: 242, 259).

Tolstoy emphasized the need to feel the "breadth and syncretism of the whole system of folk spiritual culture", the analysis of which provides an opportunity to see these sources (Толстой 1995: 122). For Slavic traditional culture, the term игрище -'playground' has long been used to describe the carnival atmosphere of the ritual complex, which organically combined songs, dances, costumes, games, divination, etc., which had both magical and aesthetic functions. In Dahl's Dictionary, the notion игрище (igrishte, playground) is characterized, in particular, as посиделки, вечорки, особ. святочные (Даль 1955: 7) (get-togethers, parties, esp. Christmastide). At the same time, the types of traditional roundabouts and carnival games can be distinguished by their structural and aesthetic features. The latter, in particular, is characterized by tragic-farcical nature and a bright variety of figurative and artistic means, including plastically expressive doll, colorful costumes, dressing, singing, dancing, instrumental music, verbal forms, etc. (Гусев 1993: 91). Herewith the conceptual coherence of the carnival and masquerade in relation to the Orthodox, in particular Slavic ritual tradition can be traced to the example of modern New Year's masquerade games from the Epiphany to St. John's Day, living among ethnic Macedonians in Kali Vrysa, Volak and Petrus, Drama region (Greece) (Мишкова 2017: 300).

For the traditional culture of Serbia, for example, it was not appropriate to use the term 'carnival' until the end of the twentieth century, although in some places there are references to similar forms of celebration in small towns, typologically similar to the carnival (Делић 2018: 52). The equivalent name in the territory of Serbia and the South Slavic cultural space is the common one - Serbian покладе 'Shrovetide', despite the existence in the Orthodox tradition of four relevant periods associated with the carnival as a "performance of the boundary time zone" on the eve of the great Christian holidays (Марјановић 2011: 11). Semantic "attraction" and lexical-semantic correlations of the concept of 'game' with the nominative field of "fun, joy, pleasure", derived from the ancient Slavic *vesel-, causing the synonymy of the verbs 'играти' and 'веселитися', based on common 
to them importance of vitality, justified by N. Tolstoy. One of the "main semantic spheres" of such "rapprochement" is "the feast of Christmas and the ritually and mythologically associated New Year (St. Basil's Day)", when the magical meaning of well-being wishes is inseparable from the general semantics of the sacred beginning (annual and life cycle) (Толстой 1995: 294-312).

The universalism of the game, which in traditional culture was not opposed to serious or ordinary entertainment, as opposed to everyday practice, was an integral part of life, thus forming, representing and subordinating reality, so determined the syncretism of ritual action. Based on ideological syncretism, as well as a combination of different arts - poetry, music, choreography, theatrical forms, etc., folklore art system, in general, the whole folklore tradition in general, becomes the most striking example of the game concept of art (Киченко 2002: 162).

Many important works are devoted to the study of the "huge world of folk laughter culture" presented in it various forms of folk-festive merriment, which have been outlined by Bakhtin. Bogatyrev repeatedly addressed this topic, analyzing the rituals, in particular, the Christmas and New Year cycle, on the basis of broad Slavic material. Bogatyrev's idea of the multifunctionality of cultural phenomena corresponded to Bakhtin's theory of polyphony and was formulated by him in relation to magical and dramatic rites (Микитенко 2018). Revealing the connection between theatrical art and folklore, Bogatyrev turns to the carnival atmosphere of folk performances and customs of Shrovetide, which had a "wildly cheerful character" (driving a bear), to the role of a mask in carnival entertainment, when the costumes played various scenes the power of humor that "prevailed during folk festivals, village carnivals and ceremonial games". Emphasizing the importance of improvisation as a necessary prerequisite for preserving tradition, Bogatyrev considers the dynamics of verbal communication of ritual action, defining the formulas of ritual New Year and Christmas wishes as "folk art forms closely related to ritual and magic", whose "dominant function" is "creating", "magical or religious" (Богатырев 1971: 14). Bogatyrev's attention, as before Veselovskij, and later N. Tolstoy, is attracted by the rite polaznik (also polazenik, polozajnik - the first guest who visits the family on Christmas Day to perform specific rituals), which he analyzes on a wide geographical material, defining the main ceremonial features of the arrival of the first guest (Christmas, New Year, etc.), which brings happiness or misfortune, and "treat or gift to the guest" (Богатырев 1934: 260). "Remnants of pre-Christian times" were observed in the ritual actions of the polaznik, as well as in practice to foretell prosperity, to kindle a fire (Китевски 2002: 104). 
Bogatyrev, arguing with Veselin Chaikanovich ("Chaikanovich's unsuccessful attempt to explain the rite polaznik from the cult of ancestors"), did not reject such a connection, but at the same time emphasized that the New Year and Christmas rites are a "conglomeration of rites purposes". At the same time, "the explanation of the rite of one Slavic people with the help of the same rite of another people is easier and more convincing than its explanation with the help of similar rites in ancient peoples" (Богатырев 1932: 112). The rite of polaznik as an example of "unity and organic connection" of different types of folk art has been considered in many works of Bogatyrev, in particular for a comparative analysis of different types of folk art - "art of speech, art and choreographic art", namely those of its forms which are connected "with a rite and magic" (Богатырев 1971: 422). Noting the various variants of the existence of magical acts, rites and games, Bogatyrev gives examples of "games-performances" performed by many "actors", both in the context of family and calendar rituals (Богатырев 1971: 196). In particular, in many villages of Transcarpathia at Christmas "scenes were played" that were structurally "carnival playgrounds", and "among the actors were Herod, soldiers, 'Jew', goat, etc."; spoken verbal texts (kolyadki) became a supplement to the magical actions of the participants (Богатырев 1971: 211). It was proved that the ability to reveal "bright theatrical features" is due to the openness of the text of the calendar rite as organized in a fairly clear and consistent form, at the same time it is open system that combines ritual magical functions of action with the perception of it as "theater, as performances, as entertainment".

Usacheva, author of an article about the polaznik in the ethnolinguistic dictionary Slavic Antiquities, as well as other publications (Усачева 2009; Усачева 2002), notes that the rite, losing the magical-sacred essence, but retaining the forms defined by tradition, becomes "in something else - in a game, a spectacle, a drama". At the same time, dramatic and theatrical elements in the structure of the action, in particular the carnival procession, gradually begin to dominate, displace ritual, become spectacular and playful (Усачева 2002: 306). This thesis is confirmed in Tolstoy's conclusion that often opposite and even incompatible in other rites ritual and theatrical elements in the customs of the Christmas and New Year cycle show "typical syncretism", so the development of theater on the path "from ritual to spectacle" can be traced different versions of the festive (Jamalar) rite (Толстой 1995: 119). 


\section{Modern theatrical carnival holiday: Macedonian Vasilitsa}

Theater critic Katerina Petrovska-Kuzmanova, analyzing the Vasilichar carnival in the village Vevchany, as a cultural performance and an example of "folk drama", emphasizes the importance of "play", which "creates action", distributes roles and contains a "theatrical invariant" of the rite, thus becoming a prerequisite for its development from "magic play to ritual action" and folk drama. During the transformation of the rite, which goes through several stages, its magical and symbolic functions are gradually lost, while household and humorous, entertainment and entertainment elements become dominant, which is proposed to be defined as "customary travesty" (Петровска-Кузманова 2006: 68; Anguélova-Georguéva 1975: 361).

Observing today the course of the ceremony in the village Vevchani, researchers distinguish its separate structural parts - one is a continuation of the rite and is intended for villagers (visiting houses with masked characters or water sources on the evening of January 13, greeting residents named Vasyl, etc.), the other part - carnival procession - represents a transformation detachment action in a folklore spectacle and is intended for both residents and guests. Thanks to the expressive play of the participants and the bright symbolism of the folk village drama, the culmination of the Vasilichar ritual action is achieved, which consists in depicting the end of the old and the beginning of the new year. Characters, masks, verbal texts (monologues and dialogues), stage, scenography, audience, etc. become the direct "dramatic elements" of the Vasilica ritual action - both traditional and modern (Китевський 2009: 89; Петровска-Кузманова 2006: 70). Among the most important theatrical elements are traditional and modern masks and costumes, improvisation and acting "initiative", as well as the audience, which provides communication of folk drama participants with the audience, often causes improvisation by live intervention in action, evaluates the "success" of the holiday, choosing the "best" mask, etc.

Vasilichar games, which were traditionally performed in the center of the village, in the alleys and in the houses, never lacked spectators. "Sometimes the public," says Kitevsky, are residents of the town, sometimes members of one family. Spectators are arranged in a semicircle or circle, and when the drama took place in the center of the village, the audience watched from the balconies of houses" (Китевський 2009: 90). The space in which the action takes place is an important structural feature of the carnival, which is changing today: a common space integrates a person into a wider community, while private space (house) remains collectively, and events are transferred to public, open street space in the middle of the village. The atmosphere of the street is opposed to the peace of the house and 
directs the flow of energy formed by the human mass, which is in the center of the common space (Марјановић 2011: 13).

The modern existence of the rite, which is largely focused on the spectator, is increasingly taking theatrical and commercial form. Involvement of the public in the festival and its active interaction with the participants of the folklore action gives the modern carnival a certain rhythm, determines the "intensity" of its holding, with the corresponding increase, culmination, decline and completion, when traditionally old masks and outfits of the participants are burned in the village center, and people discuss the results of the holiday (Петровска-Кузманова 2006: 75). If earlier the masked participants came to every house (except for those where recently somebody died), playing scenes, for which they were treated to wine and brandy, today they just walk the streets of the village, and inside the houses come mostly children (Мишкова 2017: 305).

The carnival in the village Vevchani as an "open" entertainment action is characterized by general cultural international processes, there is an imitation and imitation of famous European carnivals, including images of masquerades, including "clown" Silly August (Maced. Глупавиот Август), silly parodies of political and economic (both internal and external) events of today are relevant. The games have the form of a theatrical procession, within which parody scenes are played out, with prepared dialogues, lines and actions. "Everywhere there are jokes about politics and religion, imitating pop, hodja, as well as various fortune tellers, Gypsies or Turks, who offer everyone who comes across on the road to guess" (Петровска-Кузманова 2006: 77). Acting out group scenes, introducing new images (and forgetting old ones - devil, widow, horsemen, etc.), involving masks of politicians, government officials, transvestites, aliens, emphasizing the general idea of "otherness", "domination", exotic, borrowed from the West images, new forms of costumes, common, in particular, among supporters of science fiction and fantasy, when drawings are applied directly to the body and face (Бояджиева-Пеева 2013: 229; Здравев 1975: 371), contribute improvisational expansion of the carnival text, especially its burlesque part. The actualization of the carnival, associated with its importance as an significant event of socio-cultural life in today's globalized world, is a testament to the syncretism of ritual and theatrical performances, the transformation of the traditional holiday into a socio-cultural phenomenon that serves as a "diachronic presentation of the community". Masked character is perceived not as a short-term change in a person's identity, but as his or her special status (Мишкова 2017: 300). 


\section{Carnival Vevchani: polyfunctionality of the text}

At the end of the $19^{\text {th }}$ and during the $20^{\text {th }}-21^{\text {st }}$ centuries European carnival, notes Vesna Maryanovich, is transformed into "a kind of entertainment with the illusion of equality between people and cultures, and lasts just as long as the social emptying of the masses". In most European countries, the structure of the carnival is commercialized over time, subject to the huge consumer industry of today, as evidenced by numerous electronic (web) pages of information media, including the Federation of European Carnival Cities (FECC), which states that the carnival is not only cultural phenomenon, but also a global industry (Марјановић 2011: 12).

Modern carnival, which exists as a living cultural practice but also as a social phenomenon, becomes a field of interdisciplinary analysis - ethnology, cultural anthropology, sociology (Мишкова 2017: 302), an important factor in studying the culture of a small town and forming "a sense of unity" or "community identity" (Сантова 2001: 149). In the modern socio-cultural context, the culture of the carnival takes on new forms and pragmatic functions (Делић 2018: 52), which was also facilitated by the UNESCO Convention (2003) on the Preservation of the Intangible Cultural Heritage. Theoretical and practical aspects of the carnival, in particular, the forms and mechanisms of stage formatting of folklore, are increasingly the subject of analysis of international conferences (Пейчева 2005: 10-13; БояджиеваПеева 2013), while the carnival attracts more and more media attention (Мишкова 2017: 313).

Vevchani Carnival, unlike many countries that began to revive carnival culture in the last decades of the twentieth century, "never faded or interrupted", and today its experience is attracted by other regional holidays in Macedonia, including the carnival associated with Pilgrimage in Strumica, Christmas celebrations in Skopje, etc. (Китевський 2009: 91). Various cultural and artistic events are becoming increasingly important with the development of cultural tourism in Macedonia, especially in Ohrid, where since 1962 is the famous "Balkan Festival of Folk Songs and Dances" (Диденко 2019).

The media emphasize the continuity of the tradition of the Vevchani Carnival for 1400 years, its cultural and historical significance, the difference from others due to the ancient culture, as well as unique and mysterious masks. The wide popularity of the holiday is emphasized, which is annually attended by more than 50.000 spectators from Macedonia and foreign countries. Every house and every street become a stage of action, which turns into a "theater without borders", where participants dressed up as "real actors" play various scenes and perform traditional ritual games. Along with modern masks, three main traditional characters remain popular - bride, 
groom and silly, as well as musicians. The rest of the masks are smaller or larger carnival groups, which with their costumes, gestures, movements, remarks, etc. sharply ridicule certain politicians, certain negative phenomena or the most noticeable "social anomalies" (Стојановиќ 2018a).

Traditionally, "allowed time of freedom" is a characteristic feature of carnival culture, when its participants, as the action continues, enjoy, as Bakhtin emphasized, "unlimited freedom", with enthusiasm "turning the world upside down". The "allowed time of freedom" of the carnival did not end during the Turkish rule or the totalitarian rule of the SFRY, and during the occupation and World War II the carnival hid illegal individuals and guerrillas (Ристовски 1975: 223; Здравев 1975: 373). Today, the carnival finds a social response to the feeling of "relativity of existing power and the dominant truth", when in the atmosphere of the holiday "life plays itself" and the boundaries between play and life are "intentionally erased" (Бахтин 1990: 284). The grotesque content of modern action increasingly focuses on public life, branding the ruthless laughter of demagoguery and hypocrisy of the authorities. "Syndrome of social tension", testifying to the connection between identity and crisis (Мишкова 2017: 306), reveals the socio-adaptive capabilities of the carnival text, including its polycentricity, thematic and aesthetic internationalization, "current" reproduction of identical copies and other characteristic for urban folklore signs of mass culture (Чебанюк 2005: 190).

An example of the creation of a grotesque allegory on the modern political life of the country is the ironic text of the "statute" of the metaphorical "Zoo Parliament", given in the information leaflets of the Vevchani Carnival. The charter states that the "Zoo Parliament" is "our pride and attraction for three decades", and the main features are the uniqueness of the composition - dominated by lions, eagles and wolves; there are a lot of bears, hyenas, crows, etc. and the principle of activity "the Zoo Parliament works on the principle of parliamentary democracy: I am for you, you are for me, he is for him, we are for us, you are for you, they are for them; when two swear, the minority profits from it, the majority suffers; consensus between parliamentary groups exists only in the case of division of prey" etc.

Lydia Stoyanovich, considering the manipulative strategies of the modern "cultural industry", draws attention to the processes of ridicule and desacralization as a resistance to such communication technologies, in which she sees "last hope" against the dominance of kitsch, "symbolic violence" and "antiquization" in Macedonia. The author emphasizes that in Macedonia "carnival games - fortunately or unfortunately, become the main cultural rituals and matrices" (Стојановиќ 2018: 300; Стојановиќ 2018а: 47).

But not only in Macedonia the surge of creative activity of the people in "Rablesian" forms, when humor and sarcasm acquire the meaning of 
"basic means of influencing the audience" and determine the activation of the resources of the holiday tradition, say researchers of folklore of social changes. The carnival atmosphere and behavior of the participants, due to the special connection between the performer and the audience, determines the specifics of the created texts in accordance with social events and moods. Tuned to the destruction of canons, such texts are both "openly or indirectly conditioned by tradition", their images, plots, symbols provide ease of recognition and perception of such works (Бріцина, Головаха 2005: 18, 19; Ivanova M. 2001; Чебанюк 2005).

Given that modern carnival as a phenomenon of global culture has crossed the boundaries of sacred time and combined the synergy of different traditions, in most countries of Europe and the world today it takes place throughout the year, promoting cultural policy, including tourism and cultural entertainment. Carnivals marked by all features of mass culture are part of the cultural practice of most countries, promote the development of tourist offers of the region or city, become its "business card", "sign", widely covered in the media, supported by local administration, attract commercial structures and create an extensive network of tourist consumption.

At the same time, a modern holiday is an endless process of consumption, and modern holiday culture has a completely different context from the traditional one (Гаєвська 2019: 100). "Rejoice in this day and spend it fun, with red Vevchani wine and homemade sausage (pork sausage - O. M.). Cheers!" (Радвете се на ден от и прајте си го ќефот, со црвено вевчанско вино и домашни луканци. На здравје!) - call flyers on the eve of the Vevchani Carnival. Given that the category of time is inextricably linked with food as the main medium of communication in culture, "folk feast" is becoming a necessary segment of the holiday, successfully used in modern tourist offers, while the carnival continues, offering menus in restaurants and a range of products (meat dishes and sausages, yeast dough products, sweets, etc.) "enhance carnival production" (Марјановић 2011: 13).

Important as a marker of cultural identity, the "gastronomic code" is listed among the five mandatory carnival "rules" - the so-called vasilichari precepts ("eat meat and sausages, whip homemade wine", have fun, play and be a vasilichar). Execution of festive actions gives the right to receive the "passport" of the citizen of "Republic of Vevchani". Such parody, at the same time similar to the official, bilingual - in Macedonian and English, "passports", which state that they are "valid for all countries", are commemorated by all present at the holiday.

Advertising actively encourages the consumption of local products; carnival behavior not only traditionally allows, but also provides for excessive consumption, including beverages. The commercial component is successfully used as an additional element of celebration, which contributes to 
the formation of the image of "I - we" community. Thus, during the carnival in the village Kali Vrisi (Greece) a special "well" is being built in the center of the village, from which wine flows and which the inhabitants call the well of Dionysius (Мишкова 2017: 304). At the same time, the introduction of the image of Dionysius, whose mask appears today instead of other traditional figures of the rite, becomes evidence of where, in which historical region the community is self-aware, what cultural heritage it perceives as its past.

Social integration and self-identification - at the level of society or the individual, are recognized as one of the most important functions of the holiday (Гаєвська 2019: 101), whose role is especially noticeable in today's globalization and multiculturalism. Today, unlike the traditional one, the holiday ceases to be a means of sacralization of fundamental cultural values, is not only part of the cultural heritage, but also a modern cultural construction, which, actualizing tradition, focuses mainly on tasks, opportunities and challenges of today. In a crisis of cultural identity, the national holiday as an integrative system acts as a connecting link of culture, providing due to its deep "emotional legitimacy" interpersonal interaction, which becomes the basis for the formation of intercultural communication. As a basic factor of self-awareness, the holiday plays a key role in the identity of the community, which is proud of its cultural tradition as a manifestation of national intangible cultural heritage, attracts it today as a resource to support tourism and socio-economic development. The question arises whether the so-called modern "marketing of tradition", which includes cultural tourism, to become an incentive for the development of the tradition itself, which is undergoing changes in modernity, losing its traditional features and local identity. Answering this question, Toncheva emphasizes that despite commercialization and inevitable changes under the influence of tourist "being", the most conscious attitude to tradition and "their" local values can be an additional factor for the development of identity (Тончева 2013: 155).

Petrovska-Kuzmanova argues about the inevitable transformation of the elements of traditional customs as a result of the changes that the modern socio-cultural situation is undergoing. Concerned that the tradition today "faces a choice - either it will not be noticed and even forgotten, or it will be stylized, dramatized, i.e. reproduced in another way," the author emphasizes that "in terms of the present and given the development of new mythology in accordance with desacralization of rituals and activities of the mass media, both options are quite possible", so it makes no sense to try to "actualize" the custom and "restore" it in modern society (Петровска-Кузманова 2006: 82).

In the "classical meaning of the word, - stressed R. Ivanova, - folklore is an intricate system of culture, closely tied up with the calendar of patriarchal man, as well as with his family and settlement life in the past. This system has its own intrinsic meaning, its symbols, containing the people's 
concepts and ideas of life". Now "the stage clears the way for a change and development of folklore as a stage art and turns it into a specific form of folklorism" (Ivanova R. 2001: 288-289).

Folklore as a culture, and carnival action as one of its most relevant modern forms, perform somewhat different functions today than in the traditional ritual sphere, while acquiring special significance in terms of pragmatics and socio-cultural communication, where they become an important factor in social dynamics. Traditional forms that meet the spiritual needs of modernity gradually become modernity, crystallizing, layering and reproducing in the spheres of mass culture and transformed tradition. Perceiving this process as natural, we will try to define the carnival in Vevchani, paraphrasing the words of Ilya Velev - as an example of "modernized folk tradition, but also as the traditionalization of folk modernity", so that "man is neither able to escape from time nor get lost in the past" (Велев 2009: 87).

\section{Bibliography}

Anguélova-Georguéva, Rossitsa (1975). La culture théâtrale folklorique chez les Slaves du Sud à travers leurs coutumes et leurs jeux d'hiver en travestis et avec masques. Македонски фолклор 15-16, 353-362.

Ivanova, Miglena (2001). "Carnivalesque" elements of the student protest rallies in Sofia and Belgrade (Analysis of media coverage in Sofia dailies). Македонски фолклор 58-59, 279-286.

Ivanova, Radost (2001). Folklore in the post-socialist Balkans. Forms of preservation and development. Македонски фолклор 58-59, 287-292.

Lozica, Ivan (1997). Hrvatski karnevali. Zagreb: Golden marketing.

Mirchevska, Mirjana P. (2008). Rituals with masks in the Republic of Macedonia with a special focus on the 'Twelve Days'. The Ritual Year and History. The Ritual Year 3. Strážnice: National Institute of Folk Culture, 160-166.

Анастасова, Екатерина (2004). Традиционни обреди и празници. У: Сантова, Мила Х., Димитрина Н. Кауфман, Албена Л. Георгиева-Ангелова и др. (ур.). Живи човешки съкровища - България. София: Академично издателство „Марин Дринов", 17-32.

Бахтин, Михаил М. (1990). Творчество Франсуа Рабле и народная культура средневековья и Ренессанса. Москва: Художественная литература.

Богатырев, Петр Григорьевич (1932). „Полазник“ у южных славян, мадьяров, словаков и украинцев. Опыт сравнительного изучения славянских обрядов. У: Lud Słowiański, t. 3, zeszyt 1, dział B, Kraków, 107-114.

Богатырев, Петр Григорьевич (1934). „Полазник“ у южных славян, мадьяров, словаков и украинцев. Опыт сравнительного изучения славянских обрядов II, Y: Lud Słowiański, t. 3, zeszyt 2, dział B, Kraków, 212-273. 
Богатырев, Петр Григорьевич (1971) Вопросы теории народного искусства, Москва: Искусство.

Бояджиева-Пеева, Емилия (2013). Научна конференция с международно участие „Маскарадните игри - визуален разказ“. Перник, 1 февруари 2013. Български фолклор, 5, 227-231.

Бріцина, Олеся, Інна Головаха (2005). Карнавал революції. Критика 89, 17-19.

Велев, Ілія (2009). Фольклор і фольклористика - традиція чи сучасність. Народна творчість та етнологія 3, 85-87.

Виноградова, Людмила Николаевна (1995). Гадание. У: Н. И. Толстой (ред.) Славянские древности. Этнолингвистический словарь, Т. 1. Москва: Международные отношения, 483-486.

Гаврилюк, Елеонора (1999). Вступне слово. Народознавчі Зошити 2, 6-11.

Гаєвська, Тетяна Іллівна (2019). Сучасні свята - механізми та умови укорінення „нових-старих“ свят: комерціалізація свята. Культурологічна думка 15, 97-103.

Гусев, Виктор Е. (1993). Карнавал р., б., у. У: К. П. Кабашников (ред.), Восточнославянский фольклор. Словарь научной и народной терминологии. Минск: Навука і тэхніка, 108-109.

Делић, Лидија Д. (2018). Карневалско устројство света, контекст, жанр: „Опет то, али друкчије“. Карневализација у српској књижевности. Научни састанак слависта у Вукове дане 47/2. Београд: Филолошки факултет, Међународни славистички центар, 51-62.

Даль, Владимир (1955). Толковый словарь живого великорусского языка. 2. Москва: Издательство иностранных и национальных словарей.

Диденко, Наташа (2019). ). „Балканскиот фестивал на народни песни и игри“ во функција за развој на културниот туризам во Охрид. Фолклористика 4/2, 45-63.

Здравев, Ѓорѓи (1975). Играта „Џамала“ во Агино село (Кумановско). Македонски фолклор 15-16, 369-373.

Китевски, Марко (2001). Македонски празници. Скопје: Менора.

Китевски, Марко (2002). Студии за македонскиот фолклор. Скопје: Институт за македонска литература.

Китевський, Марко (2009). Драматичні елементи у фольклорі - традиція та актуальність. Народна творчість та етнографія 3, 88-92.

Киченко, Олександр (2002). Фольклор як художня система (пробеми теорії). Дрогобич: Каменяр.

Константинов, Душан Хр. (1975) Кон приучувањето на маските во зимските обичаи во Македонија. Македонски фолклор 15-16, 375-378.

Левкиевская, Елена Е. (2004). Переворачивание предметов. У: Н. И. Толстой (ред.) Славянские древности. Этнолингвистический словарь, Т. 4. Москва: Международные отношения, 679-681.

Маленко, Димче (1975). Некои белешки за зимските обичаи и обичајни песни од Охрид. Македонски фолклор 15-16, 383-385.

Малинов, Зоранчо (2006). Новогодишниот обреден комплекс во ОхридскоСтрушкиот регион. У: Боне Величковски (ур.) Фолклорот во ОхридскоСтрушкиот регион. Скопје: Институт за фолклор „Марко Цепенков“, 205-224. Марјановић, Весна (2011). (ур.) Милош Матић. На крају и на почетку карневал. Београд: Етнографски музеј у Београду. 
Микитенко, Оксана (2018). Допринос Петра Г. Богатирјова и Никите И. Толстоја проучавању карневализације у фолклору Словена. Карневализација у српској књижевности. Научни састанак слависта у Вукове дане 47/2. Београд: Филолошки факултет, Међународни славистички центар, 31-40.

Мишкова, Иглика (2017). Маскарадът в Драмско. Български фолклор 3, 300-315. Младеновски, Симо (1975). Џаламарството во Козјачијата (Кумановско). Македонски фолклор 15-16, 379-381.

Некрылова, А.Ф. (1993). Карнавальность р., Карнавальнасць б., Карнавальність у. У: К. П. Кабашников (ред.), Восточно-славянский фольклор. Словарь научной и народной терминологии. Минск: Навука і тэхніка, 110.

Николовски, Ристо (1992). Периодични и пригодни ритуали во село Свиништа (Охридско). Македонски фолклор 50, 191-214.

Пейчева, Лозанка (2005). Копривщица 2005: фрагменти, образи, размисли. Български фолклор 5, 6-28.

Петровска-Кузманова, Катерина (2006). Народната драма во Охридско-Струшкиот регион. У: Боне Величковски (ур.) Фолклорот во Охридско-Струшкиот регион. Институт за фолклор „Марко Цепенков“, 67-84.

Плотникова, Анна А. (2004). Этнолингвистическая география Южной Славии. Москва: Индрик.

Поповски, Аритон (1975). Водичарските обичаи и песни во с. Битуше (Река). Македонски фолклор 15-16, 243-252.

Раденковић, Љубинко (2019). О симболици обредног понашања у народној култури Срба. Глас CDXXIX. Београд: Српска академија наука и уметности, Одељење језика и књижевности 31, 95-132.

Ристовски, Блаже (1975). Машките еротските народни песни околу коледниот огин во некои места во Македонија. Македонски фолклор 15-16, 219-228.

Сантова, Мила (2001). Култура и традиция на малкия град. София: Академично издателство „Проф. Марин Дринов“.

Скиба, Микола (2004). Ціннісний зміст і функції храмових свят як чинник трансформацій у структурі локальної ідентичності українських селян XX поч.. XXI ст., Народознавчі зошити 1-2, 30-36.

Спировска, Лепосава (1975). Некои драмски елементи во обичајот Василица во село Лисиче (Титоввелешко). Македонски фолклор 15-16, 363-367.

Стојановиќ, Лидија (2018). Културна индустрија - индустрија на културата (ре-митологизација и манипулативни стратегии). XVI међународни конгрес слависта. Тезе и резимеи 2, Београд: Међународни комитет слависта, Савез славистичких друштава Србије, 300.

Стојановиќ, Лидија (2018а). Архиви на меланхолија, Скопје: Лидија Стојановиќ, 2018.

Толстой, Никита Ильич (1995). Язык и народная культура. Очерки по славянской мифологии и этнолингвистике. Изд. 2-е, испр. Москва: Индрик.

Тончева Веселка (2013). Локална идентичност - употреби на термина. Български фолклор 5, 153-168.

Усачева, Валерия Васильевна (2002). Театральные элементы в структуре славянского ритуального текста. У: Л. П. Солнцева (ред.) Петр Григорьевич Богатырев. Воспоминания. Документы. Статьи. Санкт-Петербург: Алетейя, 299-305. 
Усачева, Валерия Васильевна (2009). Полазник. У: Н. И. Толстой (ред.) Славянские древности. Этнолингвистический словарь, Т. 4. Москва: Международные отношения, 128-131.

Чебанюк, Олена (2005). „Помаранчева революція“ у фольклорі київських майданів і вулиць. Молода нація 1(34), 177-191.

\section{Зимски карневал у селу Вевчани (Република Северна Македонија) као модел традицијског празника и савремене културне праксе}

\section{Оксана Микитенко}

\section{Резиме}

Чланак је заснован на запажањима насталим током извођења теренских истраживања 2019. године, кад је ауторка присуствовала зимском карневалу Василица у селу Вевчани близу Охрида, који се сваке године одржава на дан Светог Василија (13-14. јануара). Повезана с новогодишњим ритуалима, светковина Василица приказује традицију обредног маскирања у периоду тзв. нечистих или некрштених дана (између Божића и Богојављења). Позната је на читавој етничкој територији Македоније, с разликама у називима учесника (василичари, сировари, џамалари и др.). Традицијска драма (тј. видови драмског приказивања) (П. Богатирјов, М. Китевски), која се изводи у току Василице, представља имитацију свадбеног ритуала и један је од елемената ритуалног понашања у коме се актуализује семантика плодности у контексту смене годишњих доба. Вевчански карневал има дугу традицију одржавања и данас је члан Међународног удружења карневала. Запажа се истовремено присуство традицијских и модерних елемената културе који стављају празник у потпуно другачији контекст, обележен процесима масовне културе и потребама потрошачког друштва. Разматрајући карневал у Вевчанима у оквирима процеса савремене глобализације, долази се до закључка да је он значајан за друштвено-економске потребе, али у исто време и као синергија традицијске и савремене празничне културе чија је улога да одржава идентитете на микронивоу и макронивоу.

Кључне речи: Република Северна Македонија, Вевчани, карневал Василица, фолклорна традиција, савремена култура

Oksana Mykytenko

Institute for Art Studies, Folklore and Ethnology

National Academy of Sciences of Ukraine, Kiev

Email: oksana_mykytenko@hotmail.com

Received: 23. 10. 2020.

Accepted: 26.12. 2020. 